\title{
Synthesis of Unsymmetrical Methylenebisphenol Derivatives
}

\author{
Samuel Guieu, ${ }^{* a, b}$ João Rocha, ${ }^{a}$ Artur M. S. Silva*b \\ a CICECO, Department of Chemistry, University of Aveiro, 3810-193 Aveiro, Portugal \\ E-mail: rocha@ua.pt \\ b QOPNA, Department of Chemistry, University of Aveiro, 3810-193 Aveiro, Portugal \\ Fax+351(234)370084; E-mail: sguieu@ua.pt; E-mail: artur.silva@ua.pt \\ Received: 05.02.2013; Accepted: 17.02.2013
}

\begin{abstract}
A simple and efficient route towards unsymmetrical methylenebisphenol derivatives is reported. This straightforward strategy avoids the use of harmful or dangerous chemicals, allowing the synthesis of highly functionalized bisphenyls with no need of protecting groups. The alkylation of the phenyl ring is selective for the para position of the hydroxyl substituent. All methylenebisphenols were obtained in a completely regioselective manner and isolated in high yields.
\end{abstract}

Key words: benzylation, phenols, regioselectivity, methylenebisphenyls

Methylenebisphenyl derivatives are a class of versatile compounds with potential applications in both medicinal and material chemistry (Figure 1). Natural derivatives have been extracted from algae and herbs, most of which presenting nonsymmetrical cores, such as forkienin (3). ${ }^{1}$ Methylenebisphenol bearing diverse substituents and methylenebisanthranilic acid and esters exhibit biological properties, such as anti-obesity ${ }^{2}$ or antioxidant activities. ${ }^{3}$ Methylenebisphenyl is a good UV absorber and, thus, it has been used in the protection of materials against UV degradation. Some simple derivatives have already found their way into industrial applications, as 2,2'- and 4,4'methylenebisphenols which are used as antioxidants ${ }^{3}$ and stabilizers of polymeric materials. ${ }^{4}$<smiles>O=C(O)c1cc(Cc2cc(-c3ccccc3)c(O)c(-c3ccccc3)c2)cc(C(=O)O)c1O</smiles>

Figure 1 Compounds based on the methylenebisphenol core: 1. Inhibitor of the phosphohydrolase activity of PTP $1 \mathrm{~B}^{5}$ that confers resistance to diet-induced obesity; 2. Hemicarcerand ${ }^{6}$ precursor; 3. Forkienin, a natural diarylmethane derivative ${ }^{1}$ and polymer precursor $^{7}$

Although methylenebisphenyl derivatives are usually synthesized using mineral acids ${ }^{8}$ or bases $^{9}$ and formaldehyde, this method only gives access to symmetrical deriv-

SYNLETT 2013, 24, 0762-0764

Advanced online publication: 06.03.2013

DOI: 10.1055/s-0032-1318394; Art ID: ST-2013-D0120-L

(C) Georg Thieme Verlag Stuttgart · New York atives. Nevertheless, a few syntheses of nonsymmetrical derivatives have been published, with important drawbacks. Bromomethylation of phenol derivatives followed by reaction with a substituted phenol, generated methylenebisphenyls as precursors of calixarenes. ${ }^{10}$ This method involves the handling of gaseous hydrobromic acid, and the use of a large excess of nucleophile to prevent multiple substitution reactions. Another synthetic pathway involves the synthesis of benzophenone derivatives, which are subsequently reduced to the corresponding methylenebisphenyls. ${ }^{11}$ This pathway has been successfully used for the multistep synthesis of forkienin (3), but its scope is limited due to the use of benzoic acid derivatives as starting materials.

Developing new tools to synthesize the methylenebisphenyl core with different substituents on each phenyl rings is then highly desirable, as it would enlarge the scope of potential applications by giving an easy access to a wider range of compounds.

We first tested the simple benzyl chloride or bromide in the Friedel-Craft alkylation of activated phenyl rings. Thus, benzyl derivatives were treated with phenol or salicylaldehyde in refluxing toluene (Scheme 1). Unfortunately, only starting materials were recovered. Changing to acidic conditions using glacial acetic acid as solvent, even with catalytic quantities of concentrated sulfuric ac$\mathrm{id}$, and raising the temperature to $90^{\circ} \mathrm{C}$ did not give better results. All our attempts were unsuccessful, probably due to the low reactivity of benzyl chloride and benzyl bromide. The absence of O-benzylation can be explained by the low reactivity of phenol in neutral or acidic conditions.<smiles>[X]Cc1ccccc1</smiles>

$\mathrm{X}=\mathrm{Br}$ or $\mathrm{Cl} \quad \mathrm{R}=\mathrm{H}$ or $\mathrm{CHO}$

Scheme 1 First attempts of direct benzylation of aromatic rings

As our goal was to explore the synthesis of substituted methylenebisphenyls, we decided to use a benzyl chloride derivative already bearing the desired substituents. Chloride was preferred over bromide for practical reasons: its synthesis involves hydrochloric acid, which is easier to handle than gaseous hydrobromic acid, and chloromethyl derivatives are relatively air and moisture stable. Thus, chloromethylation of salicylaldehyde and 2'-hydroxyace- 
tophenone was performed following published procedures (Scheme 2). ${ }^{12,13}$ The reaction is selective for the para position of the hydroxyl group, and the products were obtained in reasonable yields $(47-51 \%)$. Similar conditions applied to salicylic acid, 2'-aminoacetophenone and anthranilic acid only gave mixtures of starting materials with unidentified compounds.<smiles>[R]C(=O)c1ccccc1O</smiles><smiles>[R]C(=O)c1cc(CCl)ccc1O</smiles>

Scheme 2 Synthesis of the functionalized benzyl chlorides $\mathbf{4}$ and $\mathbf{5}$

In order to test the feasibility of the reaction, 5-(chloromethyl)-2-hydroxybenzaldehyde (4) was reacted with phenol in refluxing toluene, without catalyst. These conditions were used for the reaction using bromomethylphenol derivatives, ${ }^{10}$ with the serious drawback that a large excess of nucleophile must be used to avoid multiple alkylations. In our case, using one equivalent of each reactant, a mixture of starting materials, methylenebisphenyl 3 and unidentified side products were obtained. The use of basic conditions would lead to O-benzylation, so acidic conditions were tested. Glacial acetic acid as solvent did not prove to be successful, even on raising the temperature to $90{ }^{\circ} \mathrm{C}$. Addition of a catalytic amount of concentrated sulfuric acid instantly changed the reaction mixture from colorless to deep red. After two hours at $90^{\circ} \mathrm{C}$, the product was extracted with dichloromethane and filtrated over silica gel, yielding an off-white solid (Scheme 3 ). ${ }^{1} \mathrm{H}$ and ${ }^{13} \mathrm{C}$ NMR analysis confirmed the formation of pure fokienin $\mathbf{3},{ }^{1}$ demonstrating the para-position regioselectivity of the reaction.<smiles>[R]c1ccccc1OCC(=O)c1cc(CCl)ccc1O</smiles><smiles>[R]C(=O)c1cc(Cc2ccc(O)c([R])c2)ccc1O</smiles>

$3 \mathrm{R}^{1}=\mathrm{H}, \mathrm{R}^{2}=\mathrm{H} \quad 53 \%$ $6 \mathrm{R}^{1}=\mathrm{H}, \mathrm{R}^{2}=\mathrm{COMe} \quad 61 \%$ $7 \mathrm{R}^{1}=\mathrm{H}, \mathrm{R}^{2}=\mathrm{COOH} 92 \%$ $8 \mathrm{R}^{1}=\mathrm{Me}, \mathrm{R}^{2}=\mathrm{H} \quad 71 \%$ $6 \mathrm{R}^{1}=\mathrm{Me}, \mathrm{R}^{2}=\mathrm{CHO} \quad 66 \%$

$9 \mathrm{R}^{1}=\mathrm{Me}, \mathrm{R}^{2}=\mathrm{COOH} 66 \%$

Scheme 3 Scope of the alkylation reaction: synthesis of methylenebisphenols 3 and $6-9$

After selecting these conditions, the scope of the reaction was enlarged using $\mathbf{4}$ or $\mathbf{5}$ as alkylating agents, and phenol, salicylaldehyde, salicylic acid or 2'-hydroxyacetophenone as nucleophiles. ${ }^{14,15}$ Products 3 and 6-9 were obtained in reasonable to good yields (53-92\%) after simple filtration, and the substitution was selectively done at the para position of the hydroxyl substituent. The regioselectivity of the reaction was confirmed by NMR analysis and by single crystal X-ray diffraction study of 6 (Figure 2). ${ }^{16} \mathrm{We}$ tried to enlarge the scope of the reaction to aniline derivatives, but reactions with aniline, anthranilic acid or 2 '-aminoacetophenone as nucleophiles did not give anything conclusive, only mixtures of non-identified compounds.

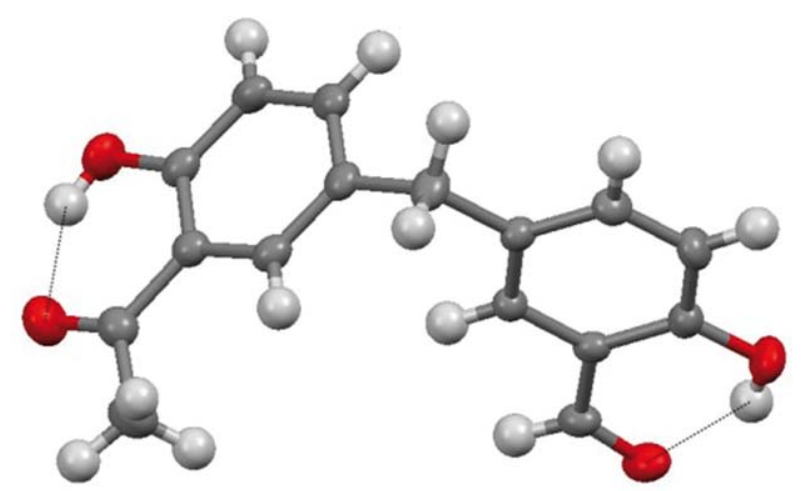

Figure 2 Molecular structure of compound 6. Thermal ellipsoids are shown at the $50 \%$ probability level, hydrogen atoms are shown with an arbitrary radius $(0.30 \AA)$, Intramolecular hydrogen bonds are shown in dashed lines. $\mathrm{C}$, grey; $\mathrm{O}$, red; H, white.

In conclusion, we have developed a simple and efficient access to methylenebisphenyl derivatives bearing different functional groups on each phenyl rings. This approach avoids the handling of gaseous hydrobromic acid and the use of nucleophile in a large excess. The products were obtained regioselectively in good yields. Application of this methodology to the synthesis of biologically relevant targets and hybrid materials is currently under investigation in our laboratory.

\section{Acknowledgment}

Thanks are due to the University of Aveiro and the Portuguese Fundação para a Ciência e a Tecnologia (FCT) for funding the Organic Chemistry Research Unit (project PEstC/QUI/UI0062/2011), the CICECO Associate Laboratory (PEstC/CTM/LA0011/2011) and the Portuguese National NMR Network (RNRMN). S.G. also thanks the FCT for a postdoctoral grant (SFRH/BPD/70702/2010).

Supporting Information for this article is available online at http://www.thieme-connect.com/ejournals/toc/synlett.

\section{References and Notes}

(1) Chen, J.-J.; Chou, T.-H.; Peng, C.-F.; Chen, I.-S.; Yang, S.Z. J. Nat. Prod. 2007, 70, 202.

(2) (a) Li, J.; Chen, J.; Gui, C.; Zhang, L.; Qin, Y.; Xu, Q.; Zhang, J.; Liu, H.; Shen, X.; Jiang, H. Bioorg. Med. Chem. 2006, 14, 2209. (b) Shrestha, S.; Bhattarai, B. R.; Kafle, B.; Lee, K. H.; Cho, H. Bioorg. Med. Chem. 2008, 16, 8643.

(3) Buravlev, E. V.; Chukicheva, I. I.; Borisenkov, M. F.; Kutchin, A. V. Synth. Commun. 2012, 42, 3670.

(4) Flick, E. W. Plastics Additives: An Industrial Guide, 3rd ed.; William Andrew Publishing: Norwich, NY, 2001.

(5) Shrestha, S.; Bhattarai, B. R.; Chang, K. J.; Lee, K.-H.; Cho, H. Bioorg. Med. Chem. Lett. 2007, 17, 2760. 
(6) Barba, V.; Betanzos, I. J. Organomet. Chem. 2007, 692, 4903.

(7) Nishat, N.; Ahmad, S.; Ahamad, T. J. Appl. Polym. Sci. 2006, 101, 1347.

(8) (a) Gurvic, Y. A.; Grinberg, A. A.; Liakumovich, A. G.; Michurov, J. I.; Starikova, O. F.; Yanshevsky, V. A.; Kumok, S. T.; Styskin, E. L.; Rutman, G. I. US Patent 408469, 1978. (b) Coffield, T. H.; Filbey, A. H.; Ecke, G. G.; Kolka, A. J. J. Am. Chem. Soc. 1957, 79, 5019. (c) Bandgar, B. P.; Kasture, S. P. Monats. Chem. 2000, 131, 913. (d) Kumarraja, M.; Pitchumani, K. Synth. Commun. 2003, 33, 105. (e) Sereda, G. A. Tetrahedron Lett. 2004, 45, 7265 .

(9) Kharasch, M. S.; Joshi, B. S. J. Org. Chem. 1957, 22, 1435.

(10) (a) Böhmer, V.; Marschollek, F.; Zettat, L. J. Org. Chem. 1987, 52, 3200. (b) Böhmer, V.; Dörrenbächer, R.; Frings, M.; Heydenreich, M.; de Paoli, D.; Vogt, W.; Ferguson, G.; Thondorf, I. J. Org. Chem. 1996, 61, 549.

(11) Singh, A.; Sharma, M. L.; Singh, J. J. Chem. Res. 2008, 3, 148.

(12) Cort, A. D.; Mandolini, L.; Pasquini, C.; Schiaffino, L. Org. Biomol. Chem. 2006, 4, 4543.

(13) Klymchenko, A. S.; Duportail, G.; Ozturk, T.; Pivovarenko, V. G.; Mély, Y.; Demchenko, A. P. Chem. Biol. 2002, 9 , 1199.

(14) Typical Experimental Procedure: A catalytic amount of concd $\mathrm{H}_{2} \mathrm{SO}_{4}(0.1 \mathrm{~mL})$ was slowly added to a solution of $\mathbf{4}$ or $5(2.0 \mathrm{mmol})$ and the desired substituted phenol $(2.0$ $\mathrm{mmol})$ in glacial $\mathrm{AcOH}(5 \mathrm{~mL})$ at r.t., and the solution was stirred at $90{ }^{\circ} \mathrm{C}$ during $2 \mathrm{~h}$. The reaction mixture was then poured on ice $(5 \mathrm{~mL})$ and extracted with $\mathrm{CH}_{2} \mathrm{Cl}_{2}(3 \times 10$
$\mathrm{mL}$ ). The organic layer was washed with sat. $\mathrm{NaHCO}_{3}$, dried over $\mathrm{MgSO}_{4}$, filtrated over silica gel and concentrated under reduced pressure to afford the pure products 3 , and 6-9.

(15) Physical Data of 5-(3-Acetyl-4-hydroxybenzyl)-2-

hydroxybenzaldehyde (6): white solid; $\mathrm{mp} 130-132{ }^{\circ} \mathrm{C} .{ }^{1} \mathrm{H}$ $\operatorname{NMR}\left(300.13 \mathrm{MHz}, \mathrm{CDCl}_{3}, 25^{\circ} \mathrm{C}\right): \delta=12.18(\mathrm{~s}, 1 \mathrm{H}, \mathrm{OH})$, $10.92(\mathrm{~s}, 1 \mathrm{H}, \mathrm{OH}), 9.84(\mathrm{~s}, 1 \mathrm{H}, \mathrm{CHO}), 7.51\left(\mathrm{~d},{ }^{4} J_{\mathrm{H}-\mathrm{H}}=2.1\right.$ $\mathrm{Hz}, 1 \mathrm{H}$, aromatic $\mathrm{CH}), 7.34\left(\mathrm{dd},{ }^{4} J_{\mathrm{H}-\mathrm{H}}=2.1 \mathrm{~Hz},{ }^{3} J_{\mathrm{H}-\mathrm{H}}=8.4\right.$ $\mathrm{Hz}, 1 \mathrm{H}$, aromatic $\mathrm{CH}), 7.31\left(\mathrm{~d},{ }^{4} J_{\mathrm{H}-\mathrm{H}}=2.1 \mathrm{~Hz}, 1 \mathrm{H}\right.$, aromatic $\mathrm{CH}), 7.28\left(\mathrm{dd},{ }^{4} J_{\mathrm{H}-\mathrm{H}}=2.1 \mathrm{~Hz},{ }^{3} \mathrm{~J}_{\mathrm{H}-\mathrm{H}}=8.4 \mathrm{~Hz}, 1 \mathrm{H}\right.$, aromatic $\mathrm{CH}), 6.94\left(\mathrm{~d},{ }^{3} J_{\mathrm{H}-\mathrm{H}}=8.4 \mathrm{~Hz}, 1 \mathrm{H}\right.$, aromatic $\left.\mathrm{CH}\right), 6.93(\mathrm{~d}$, ${ }^{3} J_{\mathrm{H}-\mathrm{H}}=8.4 \mathrm{~Hz}, 1 \mathrm{H}$, aromatic $\left.\mathrm{CH}\right), 3.93\left(\mathrm{~s}, 2 \mathrm{H}, \mathrm{CH}_{2}\right), 2.60$ $(\mathrm{s}, 3 \mathrm{H}, \mathrm{Me}) .{ }^{13} \mathrm{C} \mathrm{NMR}\left(75 \mathrm{MHz}, \mathrm{CDCl}_{3}, 25{ }^{\circ} \mathrm{C}\right): \delta=204.3$ $(\mathrm{C}=\mathrm{O}), 196.4(\mathrm{C}=\mathrm{O}), 161.0(\mathrm{COH}), 160.1(\mathrm{COH}), 137.5$ $(\mathrm{CH}), 137.1(\mathrm{CH}), 133.1(\mathrm{CH}), 132.2\left(\mathrm{C}_{\mathrm{q}}\right), 130.7\left(\mathrm{C}_{\mathrm{q}}\right), 130.4$ $(\mathrm{CH}), 120.4\left(\mathrm{C}_{\mathrm{q}}\right), 119.5\left(\mathrm{C}_{\mathrm{q}}\right), 118.7(\mathrm{CH}), 117.9(\mathrm{CH}), 39.6$ $\left(\mathrm{CH}_{2}\right), 26.6(\mathrm{Me})$. ESI-MS: $m / z=271.1[\mathrm{M}+\mathrm{H}]^{+}$. Anal. Calcd for $\mathrm{C}_{16} \mathrm{H}_{14} \mathrm{O}_{4}$ : C, 71.10; H, 5.22. Found: $\mathrm{C}, 71.23 ; \mathrm{H}$, 5.36 .

(16) Crystal data: $\mathrm{C}_{16} \mathrm{H}_{14} \mathrm{O}_{4}, M=270.27$, triclinic, space group $\mathrm{P}-1, Z=2, a=6.9901(6) \AA, b=8.2805(7) \AA, c=11.7324$ (9) $\AA, \alpha=93.845(4)^{\circ}, \beta=105.754(4)^{\circ}, \gamma=93.618(4)^{\circ}, V=$ $649.77(9) \AA^{3}$, yellow block with crystal size of $0.40 \times 0.20 \times 0.06 \mathrm{~mm}^{3}$. Of a total of 3526 reflections collected, 2959 were independent $\left(R_{\text {int }}=0.0540\right)$. Final $R 1=$ $0.0627[I>2 \sigma(I)]$ and $w R 2=0.1607$ (all data). CCDC 923073 contains the supplementary crystallographic data for this paper. These data can be obtained free of charge from The Cambridge Crystallographic Data Centre via www.ccdc.cam.ac.uk/datarequest/cif. 